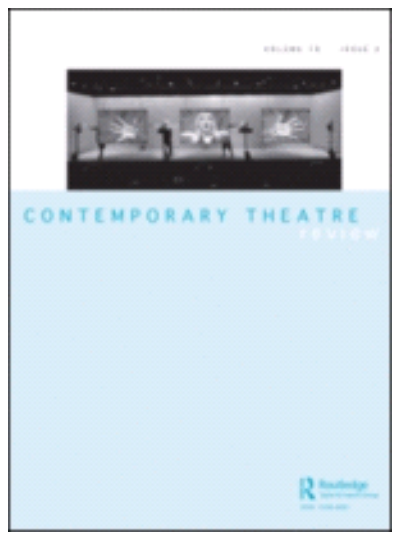

Rehearsals of the Weird: Julia Bardsley's Almost the Same (feral rehearsals for violent acts of culture)

\begin{tabular}{|r|l|}
\hline Journal: & Contemporary Theatre Review \\
\hline Manuscript ID & Draft \\
\hline Manuscript Type: & Article \\
\hline Keywords: & theatre, performance, Julia Bardsley, the weird, the wild \\
\hline \multicolumn{2}{|l}{} \\
\end{tabular}

SCHOLARONE ${ }^{\text {m }}$

Manuscripts 
If the way we construct definitions of our identity is based on the words currently in use, then Julia Bardsley creates new vocabularies to define her identity as an artist and to envision the world she longs to exist within. Bardsley's performance work comprises of highly theatrical spectacles, strange objects and garments that usually surround a fantastical persona, a world of fiction and fantasy that is communicated through film, visuals, textures, language and sound. Bardsley's theatre consists in imagery that is difficult to forget, imagery that may return to us later on, a little like a dream, a perverse fantasy or an unfulfilled desire. It may return to us as something incomplete, but persistent. Something of an impossibility seems to traverse her practice, an impossibility perhaps to fully come to terms with the complexity of her imagery, the strange imagination that has envisioned such a world.

Bardsley stages her own desires and fantasies rigorously and unapologetically. Her work centres around strange personae who have strong desires and are determined to exist in their 
own terms. These personae exist in worlds other than our own. Bardsley meticulously creates these worlds and by doing so, she gives us permission to consider what our own fantastical, perverse worlds may look like. These are worlds we may actually want to exist within or fanstize about. Bardsley's personae are not afraid, they want more and push themselves to extremes to get it; their bodies are persistent, unruly, impatient, desirous, bodies unwilling to rest, settle in or settle down.

Bardsley's work may appear in various formats: in the form of a catwalk of plagues in an optimistic reading of the apocalypse and a critique of capitalism in her performance Aftermaths: A Tear in the Meat of Vision (2009, 2010), which is based on the Book of Revelation and in which Bardsley appears as a host or a strange prophet, who begins by delivering the message: 'let the happy endings commence'. ${ }^{1}$ She is dressed in black with long, black hair, a thick moustache, yellow contact lenses, a long tail and phallus and speaks to her audience/congregation that surrounds the cross-shaped catwalk stage, which is enveloped by four massive screens depicting images of meat, money and the prophet. Bardsley is accompanied by four plagues, four performers in costume, which wear her garments of dis-ease, full of red sores, infected protrusions and wounds (figure 1).

This is part of The Divine Trilogy, which also includes Trans-Acts and Almost the Same (feral rehearsals for violent acts of culture). ${ }^{2}$ Trans-Acts is formed of three acts: Act One: Transgression, an exhibition prologue of pinhole photographs (Dunce), accompanied by a flip book and a digital projection of foolish suicide attempts $(F o o l)$ and a box of $35 \mathrm{~mm}$ photographs (Devil); the three figures, Dunce, Fool and Devil, are the transgressors, necessary for the creative process (the names of the figures have been found in Bardsley's

\footnotetext{
${ }^{1}$ Spill Festival 2009, National Review of Live Art, 2010, Trouble Festival, Brussels, 2009. 1

${ }^{2}$ Trans-Acts was presented at National Review of Live Art, 2005, Trouble Festival, Brussels, 2005, Spill Festival 2007, Karnart, Portugal 2008 and Almost the Same (feral rehearsals for violent acts of culture) at S.P.A.C.E. UK, Spain 2009, Queer Zagreb, 2008, City of Women Festival, Slovenia, 2008, Sacred Festival, London 2008 \& 2010, Karnart, Portugal, 2008, National Review of Live Art, 2008 and Lazio Festival, Italy 2012.
} 
personal notes, which she kindly gave me access to). ${ }^{3}$ This is material developed as part of the creative process towards the performance piece. Bardsley uses this process of making objects, garments, visuals and film, as a way of thinking and in several cases exhibits the work accumulated through this process alongside the performance itself (figure 2). The Fool, for example, is a 21-minute digital video projected on two walls and depicts a character painted in white with a harlequin red hat, prominent red vulva attempting to kill herself again and again. In Act Two: Transformation, another persona features in an installation of three peep boxes and sequence of stills, in which Bardsley in the persona of the Artist undergoes a transformation becoming in the end the mute host/ Director, who invites the audience into Act Three: Transcendence. The persona is photographed against a grid and starting naked in a skin colour bald cap, dresses herself in a green tailored suit with odd protrusions coming out of the elbow and the tummy; this is a life size installation which envelops the three peep boxes, within which Bardsley has placed what looks like several molds of large scale dental impressions. Part three of Trans-Acts is a performance for twelve, in which Bardsley interrogates her relationship with theatre by alternating between the live persona of the Director and her on-screen video persona of an Actress, in the midst of an audition for a part as a car-crash survivor, which her understudy tries to take over. In Act Three the twelve audience members, in an ultra violet room lit by black light, sit around a table, in a reminder perhaps of the Last Supper. ${ }^{4}$ Bardsley here allows the audience to experience the work up close. The set-up responds to her frustration about the distance between the audience and the act on stage in so much of mainstream theatre today, and satisfies her desire to re-configure 'the proximity of the audience not only to the performer but also to the environment and the

\footnotetext{
${ }^{3}$ You can see some of the pinhole images and read accompanying essays in Julia Bardsley, ' $u$ ' See the image of her ' $i$ ': Pinhole Photographs (San Francisco: Blurb, 2014).

${ }^{4}$ Julia Bardsley, Trans-Acts in Anna Furse, Theatre in Pieces: Politics, Poetics and Interdisciplinary Collaboration. An Anthology of Play Texts 1966-2010 (London: Methuen Drama, 2011), 155-198.
} 
objects that are equal players in the piece'. ${ }^{5}$ Bardsley has a long history with the role of the director, of course, as she has directed at the National Theatre, the Almeida, the Bush Theatre, amongst many others, and has been the joint Artistic Director of Leicester Haymarket Theatre (1991-1993) and the Young Vic Theatre (1993-1994), staging significant productions and adapting seminal plays such as Hamlet and Therese Raquin into magnificent spectacles of illusion. As Lyn Gardner writes in the Guardian, 'Bardsley is really a fascinating artist $[\ldots]$; she could have been running the National Theatre by now, but instead quite deliberately chose a different career path. In recent years she has been making inspired and unsettled work on the cusp between the theatre and the gallery'. ${ }^{6}$ Bardsley's theatre and performance practice as well as her installation work have come out of a frustration with the rigid expectations around staging canonical play texts and the resistance she experienced when experimenting with text. In her interview with Dominic Johnson, Bardsley suggests:

If you were a British director, it felt as though it wasn't legitimate to do other things as well - make installations, for example. It felt very limiting. I really admired people like Tadeusz Kantor, who was devising and performing in his pieces, but was also a sculptor, where his sculptures informed his performance work. I experienced a kind of suspicion and resistance in my desire to explore ideas and expand the notion of what theatre could be. I wanted to be a theatre artist, and it seemed very difficult to do that within an institutional theatre environment. ${ }^{7}$

\footnotetext{
${ }^{5}$ Julia Bardsley, Trans-Acts: Author's Notes in Furse, Theatre in Pieces, 158.

${ }^{6}$ Lyn Gardner in Furse, Theatre in Pieces, 157.

${ }^{7}$ Julia Bardsley in Dominic Johnson, 'The Skin of the Theatre: An Interview with Julia Bardsley', Contemporary Theatre Review 20, no. 3 (2010): 343. This is reprinted in Johnson's book The Art of Living: An Oral History of Performance Art (London: Palgrave Macmillan Education, 2015).
} 
Bardsley felt disenchanted with the conditions of directing in the UK and more specifically in London and therefore stopped thinking in terms of theatre and performance and started working more in visual art. Her desire at the time was to be a theatre artist, but on her own terms. In 2001 she received a NESTA Fellowship (National Endowment for Science, Technology and the Arts), which enabled her to re-define her relationship to theatre and her role as an artist. That process enabled her to realise that the artistic form (photography, video, sculpture, theatre) is chosen not by the artist but through the ideas themselves: 'The ideas will tell you they need to manifest in one medium or another'. ${ }^{8}$

Very often, Bardsley's performances have to do with destabilizing the norm and opening up new, unfamiliar spaces through which we may be able to redefine who we are. Driven by such ideas, I seek to open a discussion around the vocabularies with which we can discuss Bardsley's performances, which resist naming and being known, even while speaking to us intimately and directly. I am proposing a re-purposed critical language drawing from literary studies, film and science fiction to address difficult work. As such, I rehearse specific ideas again and again as a methodology towards getting closer to Bardsley's performances. Amongst these ideas are the weird, the perverse and the wild. These become tools with which not only to read the work but also to understand something of its making. Some of the theories I examine are directly connected to gender and identity (Eve Oishi and the perverse), while others consider identity only tangentially (Mark Fisher on the weird). However, identity and desire are placed in the heart of this reading. I will consider Bardsley as a maker of perverse worlds in what follows and then move on to account for Almost the Same in more detail, before opening a discussion on the weird.

\section{The perverse}

\footnotetext{
${ }^{8}$ Ibid., 343.
} 
Writing on the politics of visual perversion, Eve Oishi suggests that a perverse reader (borrowing Eve Kosofsky Sedgwick's term) is one who 'finds herself outside of socially designated categories of identity' and experiences her identity as perverse, namely as one that does not align or improperly aligns with the said categories. ${ }^{9}$ Oishi discusses a perverse refiguring of pleasure in film: 'a politics of perversity would require that we cease to look for ourselves in others and look instead for the fiction of ourselves in the fiction of others' ${ }^{10}$ Identity, in this case, is developed in the moment when we realise wholeness is impossible, which leads to a desire to look for ourselves in a fictional space that opens up more possibilities for the imagination: Oishi offers the example of her seeing other Asian people represented on the screen for the first time in the musical film The King and I. Although the Asians in the film are not exactly authentic, Oishi is able to recognise herself on the stage, and find herself 'outside of socially designated categories of identity and project[s] her feelings of dislocation onto cultural objects or texts'. ${ }^{11}$ In this case, the cultural object - the film - allows the spectator to use the fictionalised story in order to find or imagine oneself within it. Sedgwick suggests that there is a need for sites where 'meanings didn't line up tidily with each other' in which sites one can mis/identify oneself. The impossibility of full identification leads to the fictionalisation of the self and thus the articulation of some of our fictional identities.

Bardsley has often found herself not aligning or improperly aligning with the existing categories of artistic process and cultural production in the UK. This mis-alignment extends beyond the artistic, however, and also applies to the categories of identity, sexuality and desire. Bardsley's politics of perversity develops then within her artistic practice, which

\footnotetext{
${ }^{9}$ Eve Oishi, 'Visual Perversions: Race, Sex, and Cinematic Pleasure', Signs 31, no. 3 (2006): 651.

${ }^{10}$ Ibid., 668.

${ }^{11}$ Ibid., 650 .
} 
enables her to find herself (as an artist and a desiring body) in the fantasy of the worlds she herself envisions. As a maker, Bardsley creates a world within which she places oneself and in which she can articulate her own feelings of dislocation, of not quite fitting in, feeling out of place. For example, in Almost the Same, which I discuss in detail, Bardsley rehearses the experience of the feral as one that humans are not allowed to access through culture and socialisation. In her interview with Johnson, Bardsley remembers her family's German shepherd dog, having given birth to eleven puppies when she was three years old; she describes how she used to nuzzle up with them while they were breastfeeding and experiencing their sweet breath and the smell of milk and fur. Almost the Same, Bardsley suggests, 'is an opportunity to explore that feral and uncultured side - a healthy chance to howl'. ${ }^{12}$ Bardsley here opens up new spaces of subjectification through her own fiction; in her fictional characters, she finds the fiction of herself, her feral, uncultured side. Her identity, in this case, is developed and performed in her imagination and realised on the stage.

Bardsley dehabituates the normative body and ruptures habitual norms, so as to open up new spaces and modes of female subjectivity. ${ }^{13}$ She is not only a perverse reader, looking for the fiction of herself in the fiction of others, but a perverse maker, creating a fiction within which she can imagine finding the fiction of herself. ${ }^{14}$ And she does so by also using the fiction of others: John Gray, Giordano Bruno, Julia Kristeva, René Girard, Susan Sontag and Marina Warner are amongst the theorists Bardsley has turned to for her intensively researchbased creative process, which is unique in each performance and consists of a close

\footnotetext{
${ }^{12}$ Bardsley in Johnson, 346.

${ }^{13}$ Amelia Jones and Marin Blažević, 'The Voice of Death, Rupturing the Habitus', Performance Research: On Time 19, no. 3 (2014): 140.

${ }^{14}$ Bardsley discusses how she uses fictional characters, such as Medea, in the interview with Dominic Johnson. See Dominic Johnson, 'Subtle Aggressors: Julia Bardsley and Simon Vincenzi in Conversation with Dominic Johnson' in Theatre and Adaptation: Return, Rewrite Repeat, ed. Margherita Laera (London: Bloomsbury, 2014), 107-120.
} 
engagement with text, material and language. ${ }^{15}$ The weird seems to appear on both sides of my understanding of perversity: not aligning with given categories of identity leads to perversity, which in turn opens up new spaces of subjectification, within which the weird can be explored further. Feelings of dislocation or not quite fitting in are fuelled by weird, unruly desires for finding oneself in unlikely places that defy boundaries and refuse compromise. These unlikely places can indeed be found in certain performance images by Bardsley, whose weird desires, I will show, offer access to the unknown and unruly and rupture the normative body.

I begin with a detailed description of the second part of The Divine Trilogy, Almost the Same (feral rehearsals for violent acts of culture), in order to establish a clear sense of Bardsley's work and then I move on to consider specific imagery within it. My key theoretical framework in what follows is shaped by Mark Fisher on the weird and Jack Halberstam on wildness. I have opened this discussion by considering the connections between Bardsley's theatre work and a politics of perversity, following Eve Oishi's theory of perverse spectators. I have watched the documentation of this work archived by the British Library and have followed closely the script and a wealth of images, provided by Bardsley herself.

\begin{abstract}
Almost the Same
Almost the Same (feral rehearsals for violent acts of culture) consists of five parts: the audience comes through an installation of objects, drawings and artwork created as a process towards the performance. The shape of the triangle is important; there are chalk drawings on the wall indicating that the audience will be contained in a triangular space (figure 3 ). There

\footnotetext{
${ }^{15}$ Bardsley in Furse, 198.
} 
is a mannequin with a latex multi-breasted apron, its nipples protruding aggressively; a pair of unusually pointy red heels trapped into what looks like a mouse trap; also, an installation of turds placed in a triangular shape under a piece of glass with the title 'dirty protest' written in chalk on the wall. On top of each turd, creating the same triangular shape, is placed a chocolate rabbit and a series of images of Bardsley trapped behind glass with the word HELP written on it in what looks like excrement. Upon entering the theatre, the space is divided in two triangles mirroring each other, the stage and the auditorium; the auditorium seats have been covered with red velvet to form one of the triangles; the seats are numbered and lit and at the apex of the triangle there is a figure sitting. The stage area has walls in the triangular shape too and the audience is looking into the auditorium through a black projection gauze.

The first part of the live performance happens here: Bardsley appears wearing a glistening black PVC body bag which covers the entirety of her body and head and slowly unzips to reveal a strange creature, whose face is covered with a black balaclava, eyes and mouth exposed, holes framed, features accentuated; the creature wears a black leather wrestling singlet that leaves the breasts exposed either side, with her nipples covered in black tape crosses; the suit is modified to accommodate what looks like a pregnant belly. A horizontal caesarean incision opens up and the figure pulls out two unmoving, dead animals: two taxidermied hares that seem limp, soft and empty. The feral mother gives birth to the animals in a way that feels triumphant, with no agony at all. She lifts them up by the legs, the twin hares, and opens her mouth, her tongue protruding. These limp newborns are already dead, un-living; the scene is dark and the live mixed score composed by Bardsley's long-term collaborator Andrew Poppy also points towards the feral, the primal or the beast. This beast or monster seems to be staging a desire, a sexual one perhaps, that may seem unfamiliar, or intense or even offensive. The persona here seems to go beyond what we know or imagine 
about the female body, or the motherly body, and stages a strange desire: to be seen, to be animal, to be feral (figure 4).

The audience at this point has to exit the stage space and enter the auditorium. The prologue is over. This is Vivi-Section i: Nigredo. The names of each of the three parts of Vivi-section (Nigredo, Rubedo, Albedo, i.e. blackness, redness, whiteness), derive from the stages of the magnum opus in alchemy and refer to the stages of the different figures we encounter in this piece, dressed in black, red and white, which follow a journey from the feral, animal to the cultured and tamed, Bardsley tells us. ${ }^{16}$ The motherly/ monstrous figure is now in the stage area and has transformed into Nigredo: wearing a black wig on top of the balaclava, black fur coat, gloves, tights and high boots, the wrestling singlet has now been removed. In front of Nigredo, there is a large projection of an albino figure with white hair and skin, red eyes and a white surgical mask, which, when removed, reveals a cleft-palate, 'a hare-lip, a vermillion wound of the mouth'. ${ }^{17}$ This is, we learn later, an over-cultured figure, which seems to be presented in opposition to the feral, the animal on the stage. The beast mother, now a little less beast with the wig and coat, holds one hare in the mouth and growls; then lays her children onto leather triangles on the stage and buries one of them under coal. The albino figure on the projection screen regurgitates a small tail out of her mouth and speaks:

\footnotetext{
${ }^{16}$ Interview with Julia Bardsley, City of Women Festival, October 2008, https://vimeo.com/1950016.

${ }^{17}$ Julia Bardsley, Almost the Same (feral rehearsals for violent acts of culture), text and action description, unpublished text, 2. 'The strangely formed body', Rosemary Garland Thomson suggests in her book Freakery: Cultural Spectacles of the Extraordinary Body, 'has represented absolute Otherness in all times and places since human history began' (xiii). Thomson's work reveals the practices and cultural logic 'that construct certain corporeal variations as deviant' and attempts to 'denaturalise the generally accepted opposition between normal and abnormal bodies' (xvii). Rosemary Garland Thomson, ed., Freakery: Cultural Spectacles of the Extraordinary Body (New York: New York University Press, 1996), xii-xvii. Julia Bardsley in her performance Almost the Same uses imagery from people that are visually different: a figure with a cleft-palate, an albino persona. These of course are actual representations of people with disabilities. However, Bardsley stages these differently-abled bodies, because they represent otherness; they defy the norm and mock the predictable. By doing so, the artist acknowledges the cultural logic of otherness and the ways in which these figures are considered as deviant from the system.
} 
Once upon a time in a place of dirt, a dark place, a filthy place, a place of contagion, what was born to Mary - to Army, what was born times two, what was born was almost the same, nearly different. An imitation. The One with the mark of animal on her unclean lips. The Other, her wound kissed by the black knight of annihilation. Oh, the shame, the shame, the same. ${ }^{18}$

At this point in the performance, Nigredo, or the Other, as we now know, goes at the back of the stage and defecates; she then brings the little turds with her, chews on them and places them in between the two hares in a line connecting one to the other. A monstrous figure with sharp teeth appears now on the screen and marks the end of Vivi-section i: Nigredo. The next one, Vivi-section ii: Rubedo, begins with the One speaking (figure 5):

Once upon a time in a place of blood, they all shouted 'there's no room at this inn!' Only a slaughter of the innocents. The Two, the double bind, copy cats of revenge and rivalry. The Virgin Wolf says 'raw has a gender and the meat is he... she...'. She asks the man, 'what business are you in?' He smiles and says, 'I'm in the red business'. ${ }^{19}$

The Other or Rubedo emerges from the mouth of the One, as we look at the screen; she wears a plumed red leather falcon hood, red gloves, tights and high boots. On the screen we see the One in pain, holding two skinned rabbits, her nipples covered with white Xs and her thighs slathered in blood; there is a black hole above her pubic bone, a black tunnel, as if from the caesarean section, or from some horrible accident or surgical procedure that has gone wrong. Rubedo has now removed the falcon hood and is wearing a red fur coat and red

\footnotetext{
${ }^{18}$ Ibid., 3.

${ }^{19}$ Ibid., 4.
} 
wig, red balaclava, tights and boots, emerging through the open legs of the One on the screen, through the black hole that rests on her lower tummy. There is a close-up of the One's vagina with needles sticking out; the figure starts sewing up the wound. We see projected images of the skinned rabbits covered in red wool, creating the shape of a triangle or a heart, full of blood, touching their paws. The One regurgitates a piece of meat, which she passes as a gift to the Other, who rips the raw meat apart with her teeth. Vivi-section iii: Albedo starts with a white horse and a rabbit-skulled rider; the One speaks:

Once upon a time in a clean place, a place of thrall, a place of no difference, of taming and containing. Here, where the concept is immaculate, the dead are swaddled and adored. She will preserve her clean and proper body. The One replacing The Other with a failure of imagination. This ritual, this failure, this impossibility, this breath, this attempt, this life, this show, this death. ${ }^{20}$

Albedo comes forward in a white wig, white balaclava that leaves the mouth exposed, white fur coat, white tights, gloves and high boots. She opens her coat and we can see a white triangle on top of her pubic bone. On either side, there are two rabbits hanging from inside her coat, one wrapped in white bandages, the other in silver leaf. Albedo hangs this up and places a pair of white wings on top of the mummified body. The One speaks: 'These tales have made my throat dry; my voice is hoarse', the Other repeats: 'Horse' (figure 6). The One recites a series of words, and the Other repeats; these are projected in white on the wall:

Morning Mourning

Seems Seams

\footnotetext{
${ }^{20}$ Ibid., 5 .
} 


$\begin{array}{ll}\text { Hair } & \text { Hare } \\ \text { Not } & \text { Knot } \\ \text { Tale } & \text { Tail }[\ldots] \\ \text { Can't } & \text { Cunt }\end{array}$

Stoned $\quad$ Stoned $^{21}$

In the last scene of this section, the One starts throwing white rocks, which cover the live persona on the stage, whose breathing becomes slower and slower, she reaches for some chalk and writes DOG and GOD and starts barking. In the video, we see a figure holding a triangular mirror, she turns around and we realise it is Bardsley herself, in the studio where the piece has been made. In the Epilogue of Almost the Same Bardsley, in her ordinary clothes and with a non-threatening, relaxed attitude invites the audience to take a look at the objects and garments, which are all laid out in an exhibition of sorts, behind the screen and onto the stage.

\section{The weird}

The images I tend to remember most vividly in the performance described above seem to have something in common: they are images that return to me because they are rather odd, out of the ordinary. They do not quite make sense, or, if they do, they only do so through their own logic. These images are difficult to fully articulate and come to terms with. They are unusual and unfamiliar, unknown and unknowable. All of these affects I could perhaps describe as 'weird'. I want to use the term 'weird' here as a critical trope that can potentially open a conversation about difficult, unexpected, unfamiliar experiences of performance work.

\footnotetext{
${ }^{21}$ Ibid., 5-6.
} 
The term 'weird' has been used extensively to describe science fiction both in literature and film, such as the writings of H. G. Wells, H. P. Lovecraft and Edgar Allan Poe. The term has recently resurfaced to describe the films of Greek filmmakers, including Yorgos Lanthimos (Dogtooth, Lobster) and Athina Rachel Tsangari (Attenberg, Chevalier), amongst others. Terms that are currently in use include 'weird fiction', 'weird realism', or 'the new weird'. ${ }^{22} \mathrm{I}$ want to examine how the weird is used as a critical term in literary and film studies and consider how it can illuminate some of the aspects of Bardsley's work and what spaces of critical potential it may open up. I am interested in the weird as one of the building blocks of a revised critical vocabulary for thinking about difficult experiences in performance, but also as a way of opening up thinking spaces that artists such as Bardsley can occupy and inhabit.

The term 'weird' derives from the Old Norse word 'urth' meaning twisted or in a loop; it is connected to the word 'wayward', as the weird can be difficult to predict or control, because of unusual or perverse behaviour. ${ }^{23}$ The latter is also connected to Shakespeare's 'Weird Sisters' or 'Wayward Sisters' in Macbeth, referring to the witches that eventually lead Macbeth to his demise. ${ }^{24}$ It also means 'suggestive of the supernatural; of a mysterious or unearthly character', but also carries the sense of 'out of the ordinary course, strange, unusual; hence odd, fantastic.' 25 The weird may be connected to dread or horror, or simply the unknown and unfamiliar. I am interested in the weird as 'a place for potentially radical disarticulations and reformulations of tradition binaries, starting with self and other', as a space where ideas around the unusual or the odd are unpacked and articulated in relation to performance. ${ }^{26}$

\footnotetext{
${ }^{22}$ Roger Luckhurst, ‘The Weird: A Dis/orientation', Textual Practice 31 (2017): 1041.

${ }^{23}$ The definition of the weird as 'urth' derives from Timothy Morton's examination of the weird cited in Luckhurst, 1049.

${ }^{24}$ Ibid., 1049.

${ }^{25}$ Ibid., 1049.

${ }^{26}$ Ibid., 1053.
} 
Fisher, in his book The Weird and the Eerie, proposes two different forms of a preoccupation with the strange, discussing the novels and stories of Wells and Lovecraft, among others. He proposes the weird and the eerie as particular types of aesthetic experience or fascination for the outside, as 'that which lies beyond standard perception, cognition and experience'27. Fisher describes the weird, in particular, as that which does not belong. It is not a genre as such, but rather an affect or mode of experience, 'an exorbitant presence, a teeming which exceeds our capacity to represent it' (10). It may have to do with a sense of wrongness, or 'particular kind of perturbation', a deviation from the system, something that is out of place and out of time. The weird, Fisher suggests, 'brings to the familiar something which ordinarily lies beyond it', but is defiantly different from the uncanny. Its most appropriate form is the montage, 'the conjoining of two or more things which do not belong together' $(10$, emphasis in the original). The weird is a signal that 'the concepts and frameworks we have previously employed are now obsolete' and therefore we have to come up with new vocabularies and critical tropes to address this mode of aesthetic experience (13).

The weird at times refers to the post-apocalyptic or the supernatural, However, Fisher argues, the above do not necessarily have to be weird (nor is the weird necessarily related to the supernatural). In fact, he suggests, a natural phenomenon like a black hole may be weirder than vampires, creatures we recognise straight away. Fisher is interested in weird fiction, weird tales such as those published in the 1920s by Lovecraft, which are preoccupied with the question of the outside, a 'real externality, whether of time or space or dimension' as Lovecraft put it (16). The weird tale, as envisioned by Lovecraft, is neither fantasy nor horror fiction; Lovecraft is interested in 'vague, elusive, fragmentary impressions of wonder, beauty, and adventurous expectancy', as he writes in his 'Notes on Writing Weird Fictio.'(17).

\footnotetext{
${ }^{27}$ Mark Fisher, The Weird and the Eerie (London: Repeater, 2016), 8. Subsequent references to Fisher in this section are given in parentheses.
} 
Horror only seems to take place in his work as a consequence of the encounter with the unknown; it is rather fascination that seems integral to his understanding of the weird: 'the weird cannot only repel, it must also compel our attention' (17). This fascination is similar to a form of Lacanian jouissance: 'an enjoyment that entails the inextricability of pleasure and pain', a fascination that cannot be contained (17).

The weird may have to do with the fantastic, but it also, significantly, opens up 'an egress between this world and others, [...] an interplay, an exchange, a confrontation and indeed a conflict' between the two (19). There is a sense of rupture or break that seems significant when identifying the weird: this is an irruption into a familial locale or this world; a rupture 'in the very fabric of experience itself' (22). This may have to do with trauma, or with something beyond ordinary experience of time and space that may be unnameable or indescribable. Fisher remarks that the weird also happens not only within Lovecraft's novels, but also between them. For example, in his stories Lovecraft mentions frequently the Necronomicon, a book of ancient lore invented by the author, which many readers have contacted the British Library about, but which does not exist (24). The weird here 'de-realises the factual and real-ises the fictional' (24). It is sustained in Lovecraft's work because he focuses on the consistency of his fictional system. Where fantasy in film or literature naturalises other worlds, the weird 'de-naturalises all worlds, by exposing their instability, their openness to the outside' and it is this gesture that creates the feeling of the weird (29). The weird involves a heightening of sensation, which 'exceeds the parameters of ordinary experience' (30) and the threshold, the door, the egress, the curtain leads beyond this world and into the weird.

\section{Almost the Same}


Bardsley's work opens up a space that requires its own vocabulary. It is an experience that lies beyond standard conception and exceeds my capacity to represent it. Bardsley's performance Almost the Same is difficult and elusive. I only seem able to unlock some of its complexities, once I accept that difficulty as part of the work and its function. The unfamiliar or unknowable nature of the performance is easier to unpack when considered side by side with the weird. The scene in short consists in two births: the birth of the part-human, partanimal creature, the feral monster, which is born through the large cocoon, unzipping vertically; the creature comes into the light, surrounded by the softness of the cocoon's red velvet lining. The newly born feral creature, I realise, carries a pregnant belly, an extension of the wrestling singlet that protrudes from the body. The second birth takes place through a horizontal caesarean incision from which emerge the twin hares, the feral creature's children. (Later on I will focus more specifically on desire beyond the reproductive realm.) This is an unusual scene altogether. The motherly, feral figure is unlike any motherly figure I have encountered before. I am drawn towards the world of this scene, its strangeness, excess and peculiar certainty. I am fascinated by the collage of conjoining elements that I would not necessarily have anticipated side by side: the pregnant wrestling singlet, the dead feral twins. My fascination holds within it a simultaneous attraction and repulsion; I feel weird about the imagery, the sounds, the fleeting lights. I experience some kind of uneasiness or perturbation to do with the unfamiliarity of this scene, my lack of vocabulary to address it. I feel a little unsettled, but also exhilarated. There is some kind of desire that seems to disperse the scene, which does something to me. It makes me look for ways to address what the work does to me or even look for something of myself, albeit unfamiliar, within it. This work has its own logic and it is only through this logic that I am able to account for it. The weird prompts us to find new ways of articulating desire and identity. This is what Bardsley does in her making process and theatre work. The weird says: this is not enough, there must be something 
beyond language, some other space, what Halberstam calls 'a slippage between language and experience' that gives us access to the unknown. ${ }^{28}$ The sense of perturbation I experience, the coupling of overpowerment and exhilaration produces something else in me: a sense of rupture.

The conjoining of materials Bardsley uses - velvet, PVC, fur, the textures and colours as well as the fleeting imagery (fleeting because of the light going on and off), the intentional sense of wrongness, seem to work against or towards one another to create an opening of sorts, a break or tear: something breaks or something opens up, a rupture or slippage takes place. Fisher calls that a rupture 'in the very fabric of experience itself' (2). This rupture which is mirrored in the many incisions of this first scene: the unzipping of the cocoon to reveal the part-human, part-animal figure and the vertical caesarean section the monstrous mother performs on herself in order to unveil her dead progeny. And as something or something new always emerges through these ruptures, the same happens with my experience: a new mode or affect comes into focus, to do with the uncontained or unnameable, or with that which resists being known. The weird offers access to something beyond standard experience or perception; it addresses both the inside and outside, of material, fabric, body, flesh. Almost the Same seems to stage this slippage between two worlds, starting from the Prologue: Confrontation. The conflict is between the feral and tame, the animal and the cultured. The feral body onstage interplays with the overcultured body on the screen, represented by the albino character; but there is another interplay going on here between what we know and what we are about to discover, which may give rise to a process of unknowing or unlearning, a process of coming to terms with the unfamiliar and the weird. The work itself, through its incisions, caesarean sections and ruptures gives birth to its own terminology.

\footnotetext{
28 Jack Halberstam, 'Wildness, Death, Loss', Social Text 32, no. 4 (2014): 147.
} 
Bardsley stages in the first part of Almost the Same what can only be described as a driving force, an intense desire or an affect (figure 7). She does not operate within the rules of a world I am familiar with and does not produce any explanation for what she is doing on stage. What I know, however, is that watching the birth scene seems to open up a new space for me, a space of possibilities for re-imagining something; something to do with a desire that is deviant or out of place. This wild force may have to do with the desire to not quite fit in, but deviate from the system, in other words a desire for the weird. Becoming weird offers certain permissions: to not have to make sense, be rational or contained. The weird does not legitimise, but gives space to desire. It accommodates fantasies that are unfamiliar or strange and brings together disparate elements, eccentric narratives or excessive desires. This kind of desire is not about giving birth, but uses birthing as a metaphor for newness or the unknown; a metaphor for the unfamiliar and for that which does not yet have a name. This desire may be thought of, according to Peter Coviello, as extravagant, excessive or unyarded, a desire beyond the needs for reproduction. ${ }^{29}$ Discussing this, Halberstam considers what kind of world would accommodate this type of desire, a world perhaps that 'picks away at the fabric of hegemony', quietly and in insignificant ways. ${ }^{30}$ That is a world of wildness: 'there is a wild beyond the structures we inhabit and that inhabit us' ${ }^{31}$ Through wildness, we are able to access 'another realm of thought, action, being and knowing', one that allows us 'to navigate contemporary terrains of contradiction, confrontation and complicity' (JJH), The wild, then, in Bardsley's work enters into a battle with the cultured, the tame, the governable. It confronts the domesticated and obedient and uncovers what reside beyond it: the unruly and uncontrollable. This wild desire is explosive. It exists beyond culture and socialisation (JJH).

\footnotetext{
${ }^{29}$ Peter Coviello, Tomorrow's Parties: Sex and the Untimely in Nineteenth-Century America (New York: New York University Press, 2013), 10.

${ }^{30}$ Halberstam, 'Wildness, Loss, Death', 147.

${ }^{31}$ Jack Halberstam, 'The Wild Beyond: With and for the Undecommons' in Stefano Harney and Fred Moten, The Undercommos: Fugitive Planning and Black Study (New York: Minor Compositions, 2013), 7.
} 
Vivi-section: i stages this conflict twice. Firstly, we see the One next to the feral mother, who holds her dead child in her mouth and mourns and growls. The two figures, both performed by Bardsley, one on screen, the other on stage, bring about a conflict between the inside, the intellectual, the overcultured, and the outside, the animal. Secondly, both of these worlds are placed against ours, the 'real' world outside of the theatre. These two worlds, the world of the weird in Bardsley's performance and our world outside of the theatre, are in conflict with one another. This conflict could be perhaps paralleled to the conflict of the two world in Almost the Same: the inside and outside, the cultured and feral, the clean and unclear. The outside is the space of the beast and is a place of dirt, filth and contagion, a place where the mother defecates and then chews on her own excrement and uses it as an ornament, a rope to connect her two children.

There is a sense of pleasure connected with the filth, the dirt and darkness; a sense of pleasure that this place is possible in this or other worlds, perhaps even our own; a pleasure that derives from seeing that there is a place for filth and that filth remains what it is within that place. Both clean and unclean are important and could not exist without each other. On the screen, something is changing, the inside has borrowed something from the outside. The interplay between animals and humans, the dead and the living, the open and sewn up wounds mark the invasion of one world into the other, the irruption into a familial locale, through which the weird emerges. Vivi-section iii reveals the complete transformation, the infiltration of one world into another, the slippage or spillage, which gives us access to what we do not yet know. On the stage, the beast mother has transformed into the pure Other, all in white. But something is wrong with the One, who is salivating, dribbling all over the place, plastic tubes coming out of her mouth with milk running through. We realise that the tubes are connected to a multi-breasted latex apron that the One is now wearing, which we encountered in the exhibition before entering the theatre space. The stage, once the outside 
now seems closer to the pure, the sterile, the cultured, while the screen, once representing the inside, seems now messy and uncontained, one world spilling into the other. The dirty, filthy opening of the body points towards the clean and unclean, the proper and improper, the contained and uncontained, the interplay between worlds, which are already beyond ordinary experience of time and place: something is seen that is not supposed to be seen, the inside of the body, of desire, are displayed for us to witness. The weird in Bardsley's work has to do with entering a space; it is as if we are somewhere we shouldn't be. There is also a sense of something that is not quite right: we enter Bardsley's world as if we enter a body; we look inside and discover perhaps the improper and unclean, which somehow affects our own bodies and desires. We look inside this body/world and we see too much, but also not quite enough; once exposed to this world and its possibilities, we are now not ready to compromise and settle down in our own. We have seen what lies beyond the possible, beyond what we already know, and we can never undo this experience, which resembles a rupture.

Bardsley achieves some of this rupture by becoming other, or monster; by refusing categorisation. In his 'Monster Culture (Seven Theses)' Jeffrey Jerome Cohen suggests that monsters are 'disturbing hybrids' and threaten to smash distinctions; they question binary thinking and introduce a crisis, demanding 'a radical rethinking of boundary and normality. ${ }^{32}$ The monster of prohibition 'polices the borders of the possible' but by doing so it also signals other possibilities ${ }^{\prime 33}$ Monsters seem to break taboos, such as cannibalism or incest, and directly attack social rules or patriarchal norms. The monster thus appears as 'transgressive, too sexual, perversely erotic, a lawbreaker; and so the monster and all that it embodies must be exiled or destroyed'. ${ }^{34}$ Monsters are weird and wild, they do not make sense, they exist beyond culture; they are unintelligible, they refuse to be contained or assimilated. They

\footnotetext{
32 Jeffrey Jerome Cohen, 'Monster Culture (Seven Theses)' in Monster Theory: Reading Culture, ed. Jeffrey Jerome Cohen (London: University of Minnesota Press), 3-25.

${ }^{33}$ Ibid., 13.

${ }^{34}$ Ibid., 16.
} 
propose a new way of unthinking or unlearning the social and seem to want us to cross the prohibited borders, where the wild, overly erotic, perverse and strange lies. In horror films, the monstrous is produced through the conflict between the human and non-human, man and beast, Barbara Creed writes (for example in Dr Jekyll and Mr Hyde, or King Kong), the conflict between this world and another world. In Psycho, Norman Bates, the proprietor of the hotel, suggests: 'Mother is not herself today' and refers to his mother who is already dead in the attic, a mummified corpse, but also to himself as a monster/mother. ${ }^{35}$ Here the figure of the mother is staged as a monster, still gendered and living within the patriarchal order. Bardsley's monsters, her monster children and herself as the mother beast, embody a desire, a fear and a fantasy, which has to do with the other that the monster signifies. In doing so, they gesture towards what may lie beyond the prohibited borders.

This questioning of normality becomes clearer in a specific image, in the Prologue of Almost the Same. This image enables me to discuss further a certain type of desire that moves beyond reproduction. This is the image of Bardsley having just given birth to the dead hares, and lifting them up in a celebration of sorts. Bardsley here resembles an athlete, in her wrestling singlet, during a moment of victory (figure 8). This fleeting moment, which is accompanied by growling and barking and takes place on top of the velvet triangle or podium of sorts, is a victorious one. This weird, monstrous athlete with her breasts exposed holds up her trophy, which, in this strange scenario, takes the form of two taxidermied hares. But what is Bardsley's victory about? What has she won? I think this victory has something to do with having a desiring body. I read this moment as one that celebrates desire, which is uncontained and beyond control, a monstrous desire which refuses to respect the boundaries of the 'normal' or normative; it stages the image of a longing that is unruly and disruptive; a feral body that has just given an unorthodox birth to something other than the self, but at the same

\footnotetext{
${ }^{35}$ Cited in Cohen, 44.
} 
time connected with it. Female bodies tend to do such things, or so western, neoliberal society tells us. But here, in this moment, birth is not what it seems. It has rather to do with somatic and sexual excess, an excess that produces meaning beyond what society is able to conceive or contain. In her discussion of excess, Bridget Escolme suggests that theatre functions on a spectrum: on the one hand, theatre as disruptive of social structures, norms and hierarchies, and on the other theatre as contained, generated and reinforced by these structures. ${ }^{36}$ Bardsley's theatre work can be situated on the former side of the spectrum. The specific image reminds us that things can happen beyond what we know or can conceive, consciously or linguistically. ${ }^{37}$ Things can happen physically and viscerally. Desire here is vigorous and leads to exhilaration; it is a desire to desire other, to be other, to be feral, animal, or sexual in a way that is not recognisable, accepted, legitimate or contained. Sexual desire is strange and disperses the work; it is not what we have imagined, but it makes space for other, greater desires. Bardsley throws her head back her tongue sticking out, holding the creatures up in the air in a euphoric, ecstatic way: having won. Having won over succumbing to fear, having not surrendered to the banality of normative desires and rational expectations; refusing to submit to any rationality at all and instead making space for one's strange, excessive desires and impossible longings. ${ }^{38}$ This image somehow disconnects motherhood from ideas around family, stability and belonging and connects it to desire, excess and the sexual, female, desiring body. The image does not register as an invitation or suggestion, but rather as an emphatic utterance of wanting. Of course the image also holds violence, the violence that comes with death and its proximity, which may repel us. The scene is dark and its sound imposing. The lights go on and off revealing the performer's body in different

\footnotetext{
${ }^{36}$ Ibid., xxvi.

${ }^{37}$ Ibid., xxvi.

${ }^{38}$ For a further discussion on compulsive heterosexuality, motherhood and childlessness see Eirini Kartsaki, 'On Children', Performance Research: On Reflection - Turning 100 23, no, 4-5: 16-19.
} 
positions each time. But somehow the image that stays with me is this fleeting moment of victory.

Bardsley's personae do not want to settle down. They want to be seen, to be observed, to stand out, to not quite fit in; so much so that they choose to give birth through a caesarean on a wrestling suit, coming out from a PVC cocoon; this dead progeny, as well as the gesture of breastfeeding and defecating, amongst others, marks the territory of weird desires, which make space for themselves. The image of Bardsley triumphantly lifting up the two babies celebrates this moment of birth as a moment of violence and death. It is a moment, which emphatically gestures towards what lies beyond; beyond the rules and norms of western neoliberal society. As a woman in my late 30 s, bombarded by imagery of normative life narratives and under the pressures of conforming to the agenda of patriarchy, I experience a lot of pleasure watching this scene. The pleasure experienced in this moment resembles José Muñoz' description of the ecstatic time, 'announced perhaps in a scream or a grunt of pleasure' in which the temporal stronghold of normative time is interrupted. ${ }^{39}$ Here, a space is opened up, a little like the space of Wildness, in which its subjects always in conflict or disagreement with the logic of rule, can imagine what may lie beyond it. This moment of rupture and ecstatic time disrupts a normative logic and proposes new and better worlds. The future here stops being 'a fantasy of heterosexual reproduction'. ${ }^{40}$ The scene with the dead progeny held midair marks for me a moment of transition: it appears as a moment of resistance towards a type of production associated with positivity, happiness and our lives and a transition towards another place. Production here is not profitable in the neoliberal sense: it is monstrous, weird, out of place. And this is, certainly for me and Bardsley, a moment of victory. Because refusing, amongst other things, the compulsive reproductive logic of futurity opens up new possibilities for the future. Having children appears in some

\footnotetext{
${ }^{39}$ José Esteban Muñoz, Cruising Utopia (New York: New York University Press, 2009), 32.

${ }^{40}$ Ibid., 49.
} 
cases as a marker of adulthood that is connected to normative values of stability, longevity and permanence within western mainstream culture. Giving birth to progeny that is not only dead, but also feral could be read as a double resistance towards dominant ideologies of the neoliberal patriarchy. Bardsley's triumphant scene of un-motherhood seems to have no concern for structures of longevity; it embraces non-normative, weird behaviours, resisting a prescribed logic of the 'right', the 'expected' or the 'conventional'. It challenges assumptions about female desire and fantasy and gives space to weird pleasures. It emphatically articulates an uneasiness with patriarchal agendas which ignore unruly, disruptive longings. This scene of unmotherhood appears then as the culmination of my feminist reclamation of weirdness. It stands in the place of resistance and leaves a mark that is felt as significant and extraordinary.

The weird here has to do with desire, but also with identity. Perhaps identity cannot be signalled monolithically; perhaps it cannot be articulated in a linear, straightforward manner; identity, in this case, is weird. It does not belong to a specific category and cannot be pinned down; it exists through finding oneself outside of socially designated categories. ${ }^{41}$ Weird here has to do with not being able to articulate fully and at all times an identity that is everchanging and unstable. It is saying something about permission, about instability and nonconvention. Bardsley's personae stage a desire for not quite fitting in, not belonging to an intelligible category; they seem to address imagined desires and worlds that lie beyond what we know and are able to articulate.

\section{Conclusion}

\footnotetext{
${ }^{41}$ In some sense, this is what queer identity is; however, queer, as Dominic Johnson suggests, is troubling as it can function 'as a nomenclature for academic practice. In its unmooring from the troubled category of identity and the limiting rubric of sexual practice, "queer" tends to become a catch-all for a nonspecific and virtually limitless conception of transgression, a byword for any practice that resists categorisation or troubles neoliberal pride'. Dominic Johnson, Glorious Catastrophe: Jack Smith, Performance and Visual Culture (Manchester: Manchester University Press, 2012), 28. I want to propose here a new category that functions beyond the mainstream and addresses a new relationship to specific performance work.
} 
The weird is potentially a place for a reformation of desire, a rethinking of norms. It is a space, which accommodates what lies beyond the familiar, a desire which exceeds the parameters of the ordinary, marking the matrices of normativity and perversity. It reconsiders the terms, names and categories with which we understand our desires, bodies, sexualities and opens up a space in which we may not yet be able to articulate some of our longings. Bardsley destabilises the fixity and normativity of female desire; she proposes what Muñoz describes as 'other ways of being in the world and ultimately new worlds'. ${ }^{42}$ What we already have, Bardsley seems to be saying, is not enough; her desires lie beyond majoritarian belonging, normative tastes and rational expectations. ${ }^{43}$ Her theatre work interrupts the ordinary and the expected and steps out of normative worlds. Her ideological project is both anti-normative and critical of normativity. It proposes the weird as a mode of making performance work, but also, and more crucially, as a political stance for rethinking and reconfiguring desire. The weird appears therefore as a fundamental category for understanding Bardsley's work and offers the tools to consider other theatre and performance practices that require a different vocabulary to address an experience beyond standard perception. This vocabulary depends not on ordinary language, but rather on what Halberstam calls 'the grammars of madness' and demands a radical rethinking of normality. The weird then appears as a type of aesthetic experience or affect, a space for of critical potential for reading and making work as well as a critical trope for articulating what lies beyond the given categories of sexuality, identity and desire.

Bardsley's personae have an eccentric and weird relation to desire: they want to exist triumphantly, to have triumphant desires; They want to celebrate these desires, to not feel apologetic about what they want, or how much they want it. This seems to become apparent

\footnotetext{
42 Muñoz, 1.

${ }^{43}$ Ibid., 27.
} 
through the weird, the perverse and the wild: these figures are born through the conflict between human and non-human, man and beast, this world and other imaginable or unimaginable worlds. The mother here 'is not herself today.' Her desires also have to do with an insistence to not conform, to appear as irregular and lead to a rupture through which we can imagine what might lie beyond this world. Bardsley's work throws my sense of self into crisis; the work not only demands new concepts and frameworks, but also provides them. The concepts of the weird, the wild and the perverse account for or are encompassed by each other. This vocabulary is compelled by the work itself, which can only be discussed through itself, through the rupture of experiences it engenders.

Bardsley's theatre is disruptive of social structures, norms and hierarchies. It opens up a place for potentially radical disarticulations and reformulations of the self and the ways we construct the fiction of ourselves and find it in the fiction of others. Bardsley tears down the fabric of traditional theatre and stitches it back together in a way that we can see through the seams, enter them and become part of her world, knowing that this fiction can also be ours; her worlds are bold and unrepentant, calling us to cross their borders. Bardsley's monsters do not want to be assimilated or accepted, but they desire to occupy space. These monsters are weird and wild and have perverse desires. They seem out of place, or not quite fitting in; they exceed meaning and falter between a space of knowing and unknowing, revealing what may be possible beyond the confines of this world.

The weird, the wild and the perverse help me articulate something about female desire (my desire amongst others). Desire in Bardsley's performance work is excessive, perverse in the sense that it always experiences itself as out of place and wild, as it can never be pinned down. It wants more than it can have, it moves beyond what we know. The desire to give birth to/as beast, to defecate and chew on one's excrement, to enter the black hole or wound that rests on one's belly, to be the One and the Other at the same time, to give birth to 
oneself; the desire to breastfeed the beast, the dead beast, to be beast oneself, overly sexual or perverse, to appear feral or dead, is monstrous. It is also weird, as it brings together contradictory elements, which seem to rupture the very fabric of experience. The desire to hold one's bloody progeny in one's arms, swaddle and adore them, is wild. In the sense that it exceeds our ability to perceive and place it within the comfortable parameters of what we already know. It is monstrous in the sense that we have to imagine new worlds in order to discuss or repost this one. Bardsley's overwhelming, odd, excessive desires are staged here as a force; a force that is looking for its own place; it does not need to be assimilated; it does not need to be fully identified; it wants to exist, to occupy space, to open up new space in order to think about itself; because we can only think about it through itself, through its own logic. Bardsley's work stages a desire for things like the unusual and the extraordinary. Amongst these things lies desire itself, one that is sexual, perverse, overly erotic, wild and weird.

\section{List of Figures:}

Figure 1: Julia Bardsley, Aftermaths: A Tear in the Meat of Vision (2009), Laban

Conservatoire of Music and Dance, Spill Festival, image: Simon Annand

Figure 2: Julia Bardsley, Trans-Acts (2005), National Review of Live Art, image: Simon Annand

Figure 3: Julia Bardsley, Almost the Same (feral rehearsals for violent acts of culture) (2008), Sacred Festival, image: Simon Annand

Figure 4: Julia Bardsley, Almost the Same (feral rehearsals for violent acts of culture) (2008), Sacred Festival, image: Simon Annand

Figure 5: Julia Bardsley, Almost the Same (feral rehearsals for violent acts of culture) (2008), Sacred Festival, image: Simon Annand 
Figure 6: Julia Bardsley, Almost the Same (feral rehearsals for violent acts of culture) (2008), Sacred Festival, image: Simon Annand

Figure 7: Julia Bardsley, Almost the Same (feral rehearsals for violent acts of culture) (2008), Sacred Festival, image: Simon Annand

Figure 8: Julia Bardsley, Almost the Same (feral rehearsals for violent acts of culture) (2008), Sacred Festival, image: Simon Annand 


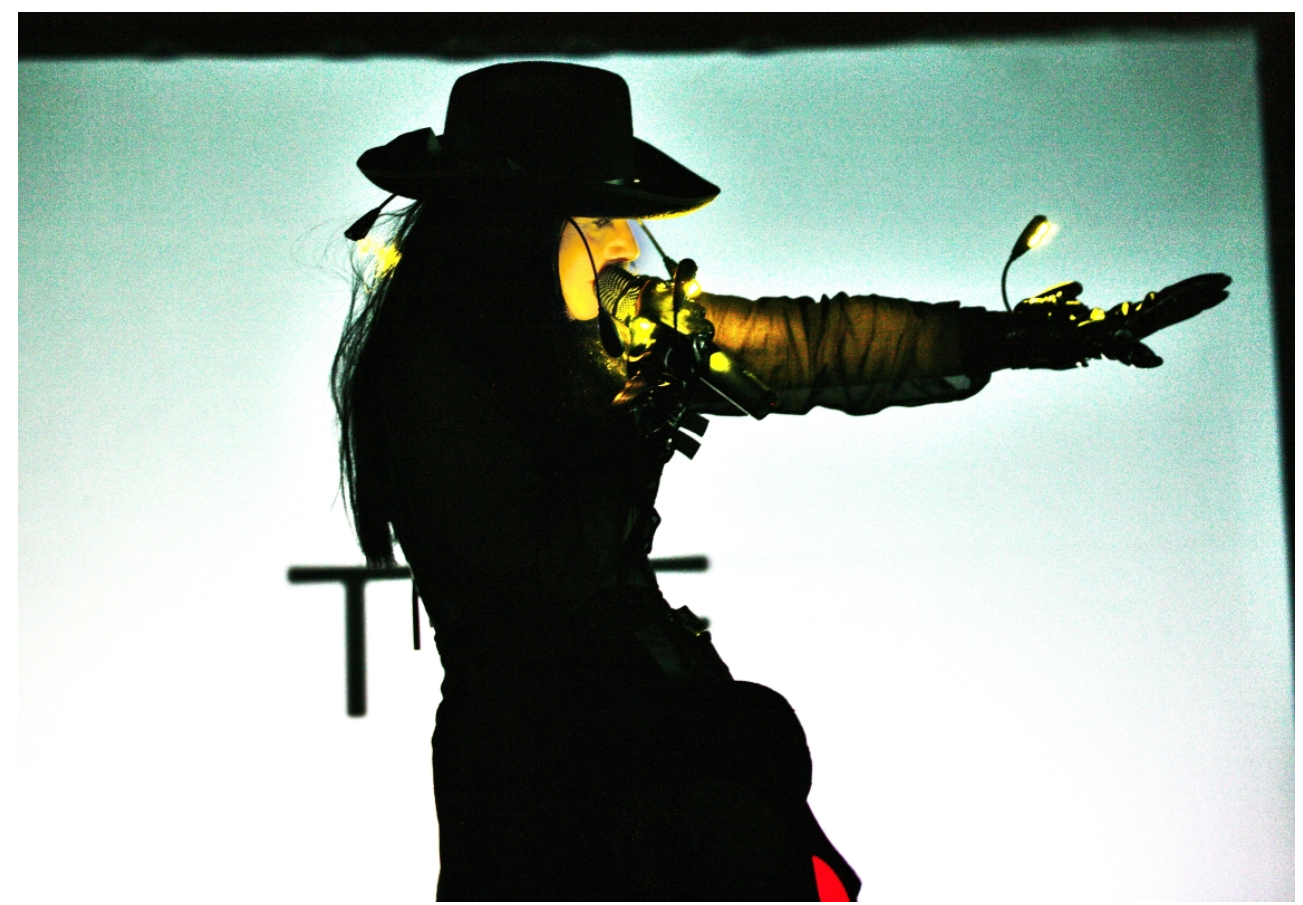

Figure 1: Julia Bardsley, Aftermaths: A Tear in the Meat of Vision (2009), Laban Conservatoire of Music and Dance, Spill Festival, image: Simon Annand

$404 \times 281 \mathrm{~mm}(300 \times 300 \mathrm{DPI})$ 


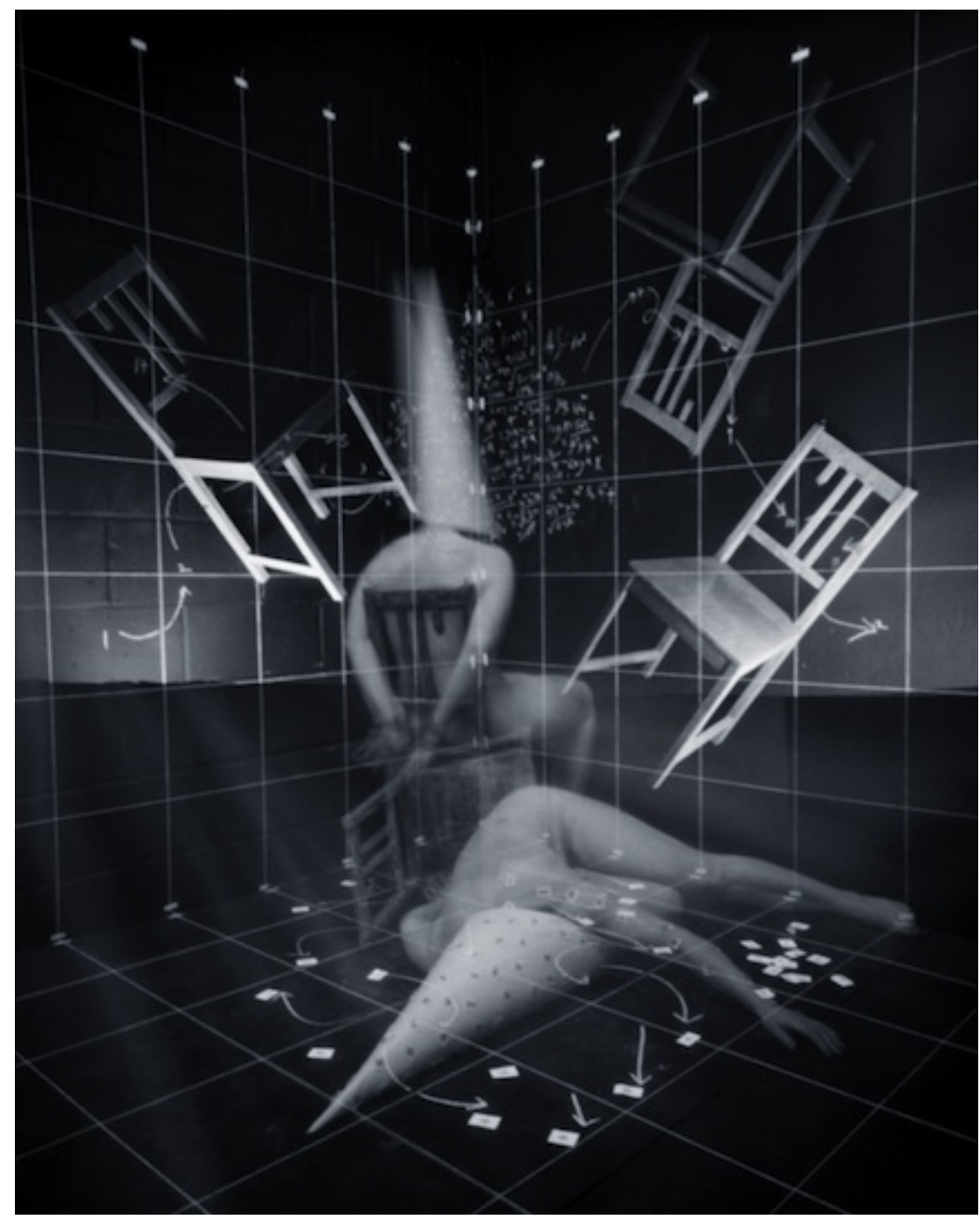

Figure 2: Julia Bardsley, Trans-Acts (2005), National Review of Live Art, image: Julia Bardsley $60 \times 76 \mathrm{~mm}(180 \times 180 \mathrm{DPI})$ 


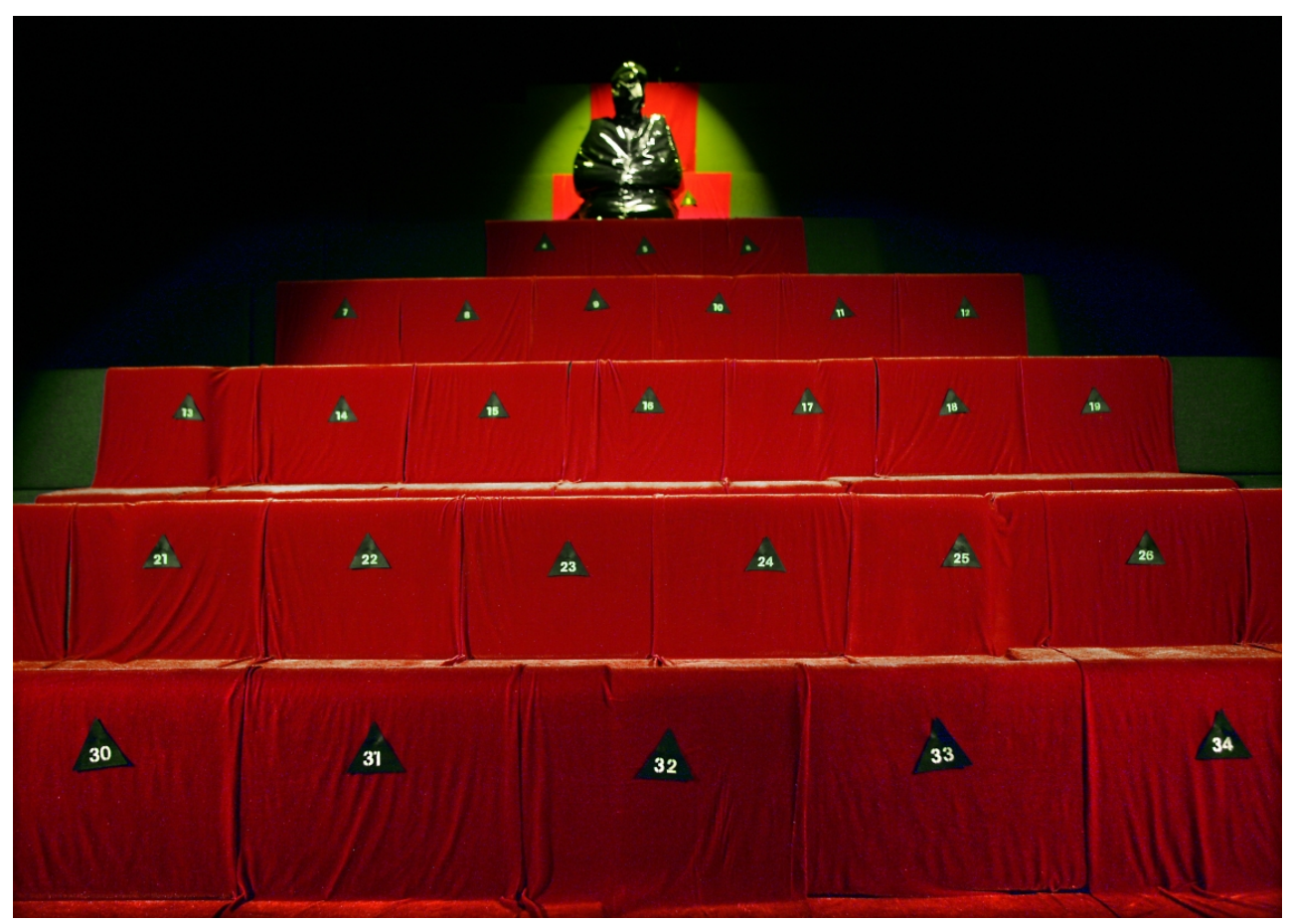

Figure 3: Julia Bardsley, Almost the Same (feral rehearsals for violent acts of culture) (2008), Sacred Festival, image: Simon Annand

$383 \times 272 \mathrm{~mm}(300 \times 300 \mathrm{DPI})$ 


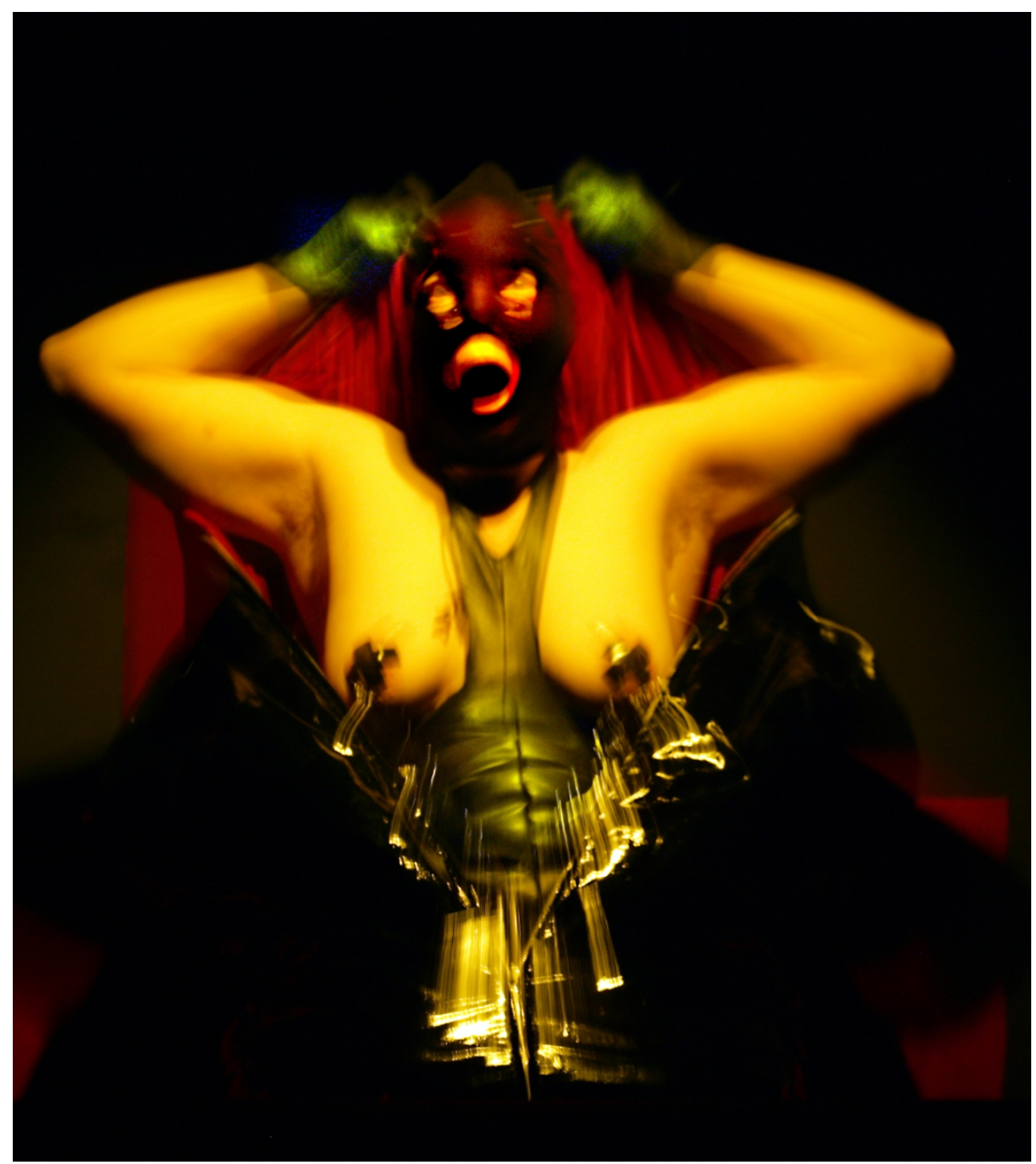

Figure 4: Julia Bardsley, Almost the Same (feral rehearsals for violent acts of culture) (2008), Sacred Festival, image: Simon Annand

$232 \times 262 \mathrm{~mm}(300 \times 300$ DPI $)$ 


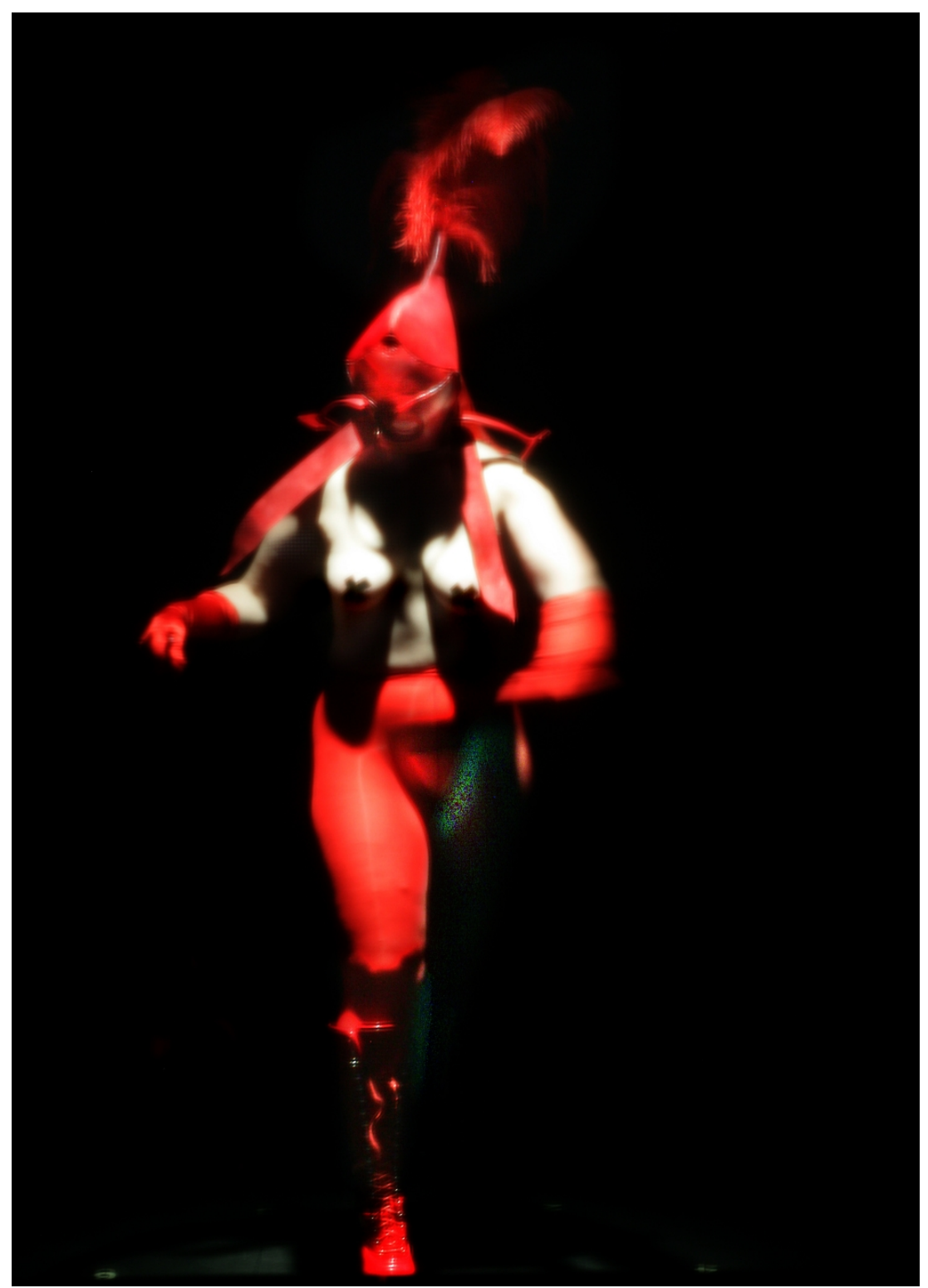

Figure 5: Julia Bardsley, Almost the Same (feral rehearsals for violent acts of culture) (2008), Sacred Festival, image: Simon Annand

$281 \times 394 \mathrm{~mm}(300 \times 300$ DPI $)$ 


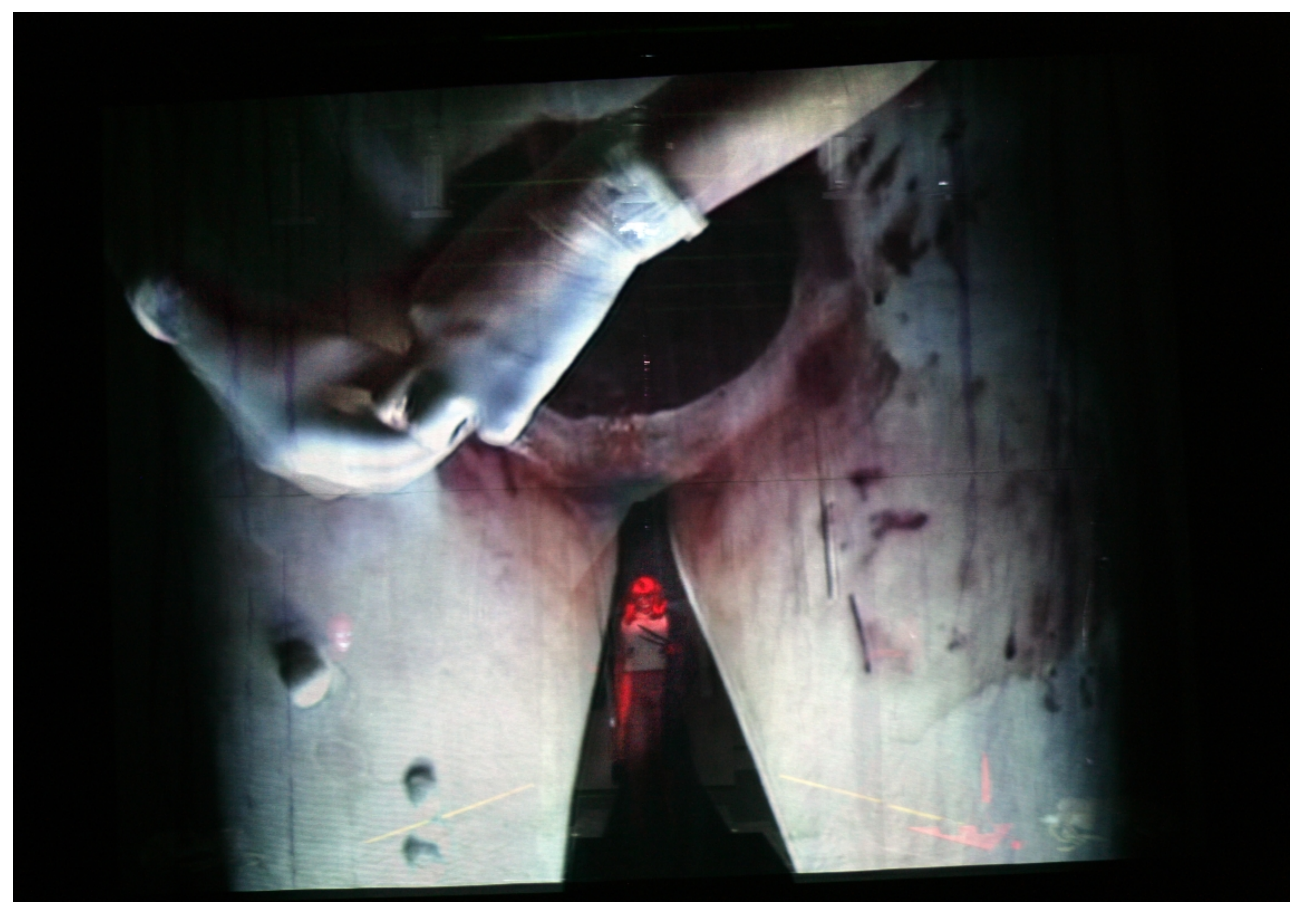

Figure 6: Julia Bardsley, Almost the Same (feral rehearsals for violent acts of culture) (2008), Sacred Festival, image: Simon Annand

$381 \times 265 \mathrm{~mm}(300 \times 300$ DPI $)$ 


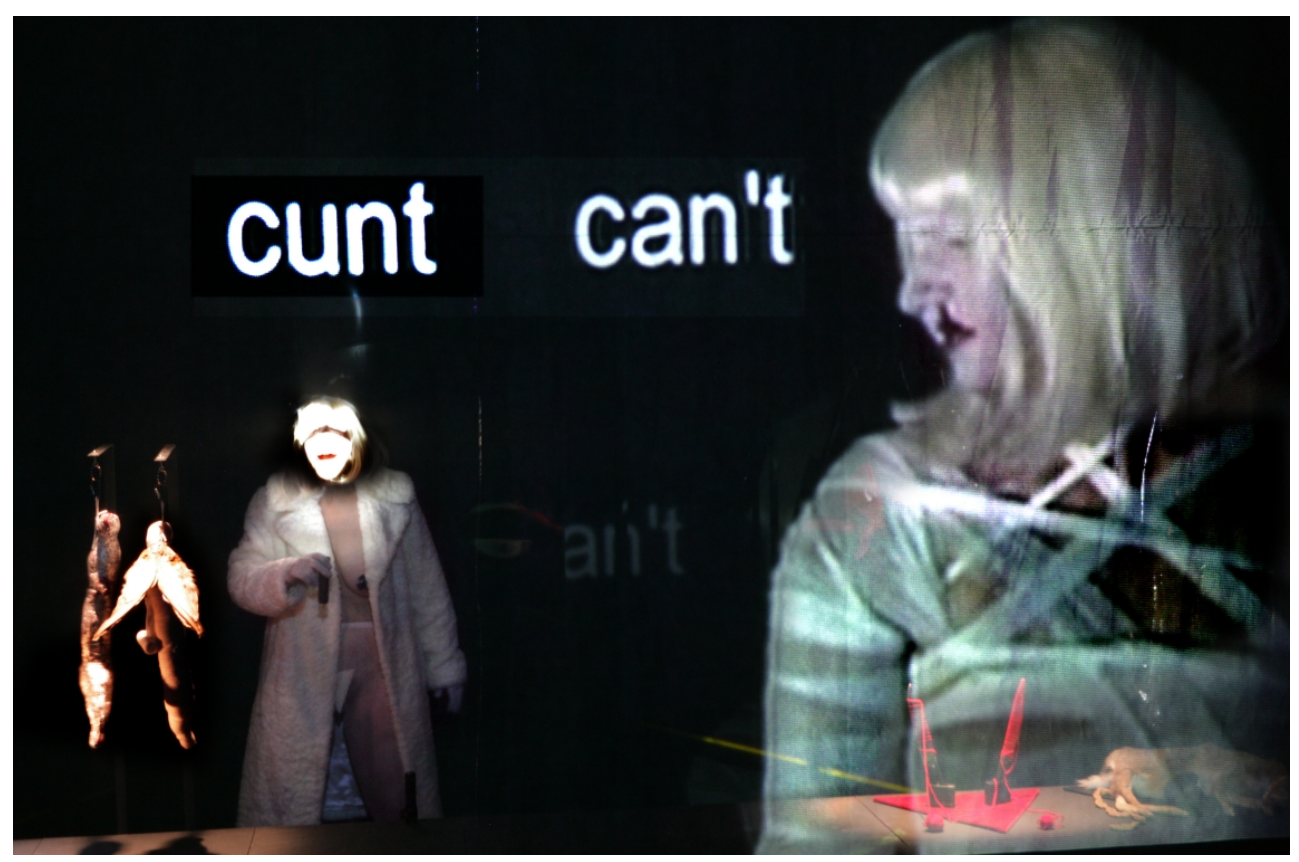

Figure 7: Julia Bardsley, Almost the Same (feral rehearsals for violent acts of culture) (2008), Sacred Festival, image: Simon Annand

$397 \times 261 \mathrm{~mm}(300 \times 300 \mathrm{DPI})$ 


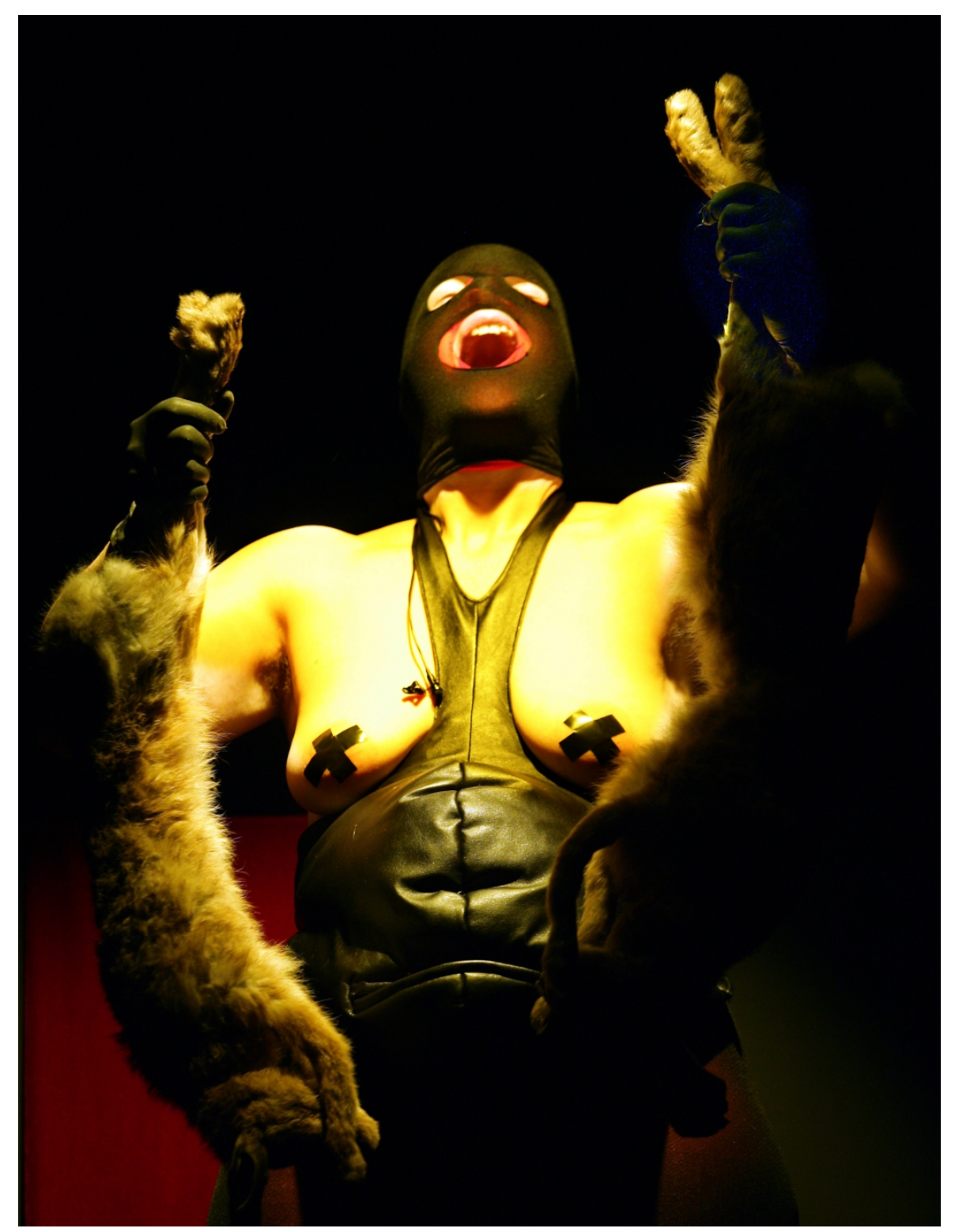

Figure 8: Julia Bardsley, Almost the Same (feral rehearsals for violent acts of culture) (2008), Sacred Festival, image: Simon Annand. All copyrights: Julia Bardsley

$268 \times 352 \mathrm{~mm}(300 \times 300 \mathrm{DPI})$ 